\title{
Notary According to Civil Law and Common Law Closely Related to International Transactions
}

\author{
Ma Junyu ${ }^{*}$ \\ *) International Researcher of Islamic College of Zhengzhou, China, Email: \\ 313395733@qq.com
}

\begin{abstract}
The world is increasingly without borders which has an impact on legal services such as the world of civilization, especially notary world. However, in reality there are still many intersections of legal systems that are increasingly widespread in the notary world like as the practice agreement letter of international trade has made the boundaries between legal systems increasingly. The differences in the use of legal systems such as Civil Law and Common Law in each country also affects the development and type of notary system. For example, the bookkeeping and business taxation system will be built based on certain legal systems across jurisdictional boundaries including land lease agreements for industries.
\end{abstract}

Keywords: Notary; Civil; Common; Law; International.

\section{INTRODUCTION}

In the development of era, it is known that notary institutions in various legal systems in the world changed. The two major legal systems rooted in the Western world both recognize notary institutions with a number of differences, they are Civil Law and Common Law. One of them is regarding the strength of proof from documents made by notaries. In various countries that are influenced by civil law, it is known that there is written evidence that can be in the form of an authentic deed or a deed under hand ${ }^{1}$.

What is referred to as an authentic deed is written evidence whose form, preparation procedure, and authorization are specifically regulated by law through a special official who is given the authority to produce it ${ }^{2}$. This official is known as a notary. Written evidence in the form of an authentic deed made by this notary has compelling evidentiary power both formally and materially. In certain cases the authentic deed is also executorial power.

Unfortunately, the authentic deed made by the notary only applies locally if it is to be used in international relations. Differences in jurisdiction mean that the signature of a notary still needs to be legalized if the authentic deed is to be used in practice of trade

\footnotetext{
${ }^{1}$ Wahyuni, \& Ma'ruf, Umar. (2020). The function of the Notary / PPAT In filing process Acquisition of Land Rights To Interests Investment in Regional Autonomy Era Based on Act No. 25 of 2007 concerning Foreign Investment. JURNAL AKTA: Vol.7, No. 2, 189-194. Retrieved from http://jurnal.unissula.ac.id/index.php/akta/article/view/7965

${ }^{2}$ Saputri, Anindia I., \& Witasari, Aryani. (2020). Notary Role In Making The Deed Of Murabahah Financing On Islamic Bank (Review On Financing Agreement In Islamic Bank Of Central Java). JURNAL AKTA: Vol.7, No. 2, 229-236. Retrieved from http://jurnal.unissula.ac.id/index.php/akta/article/view/7874
} 
and law abroad ${ }^{3}$. This legalization is carried out to ensure that the notary's signature is correct even though it does not include the truth of the contents of the act ${ }^{4}$. The legal basis is Staatsblad of 1909 No. 291 concerning the Legalization of Signatures and on the Ratification of the 1961 Vienna Convention on Diplomatic Relations and its Operational Protocols. This legalization is different from what is meant in the Law on the Position of Notary Public. ${ }^{5}$

\section{METHODS}

The method used in this research is doctrinal approach. This research examines the implementation of Notary according to Civil Law and Common Law related to International Transactions. This research is descriptive analytical which can be easily find out the problems (cases) associated with other related phenomena or symptoms and explain about the implementation of legislation in each different countries and systems. And the data collected in this study can be classified into two, namely primary data from field research and secondary data from literature studies ${ }^{6}$.

\section{RESULTS AND DISCUSSION}

Civil Law and Common Law are both different legal systems. Satjipto Rahardjo ${ }^{7}$ in his book "IImu Hukum" argues that in this world we do not find just one legal system, but more than one. The legal system referred to here includes elements such as: structure, categories and concepts. The differences in these elements result in differences in the legal system used ${ }^{8}$.

Furthermore, Satjipto said that we know two different legal systems, namely the Continental European Legal System and the British Legal System. It is also customary to use the designation Roman-German Legal System or Civil Law System for the former, and Common Law System for the second. The main characteristic of Civil Law is that this system uses the basic division into civil law and public law such categories are not recognized in the Common Law system ${ }^{9}$.

\subsection{Characteristics of The Civil Law System}

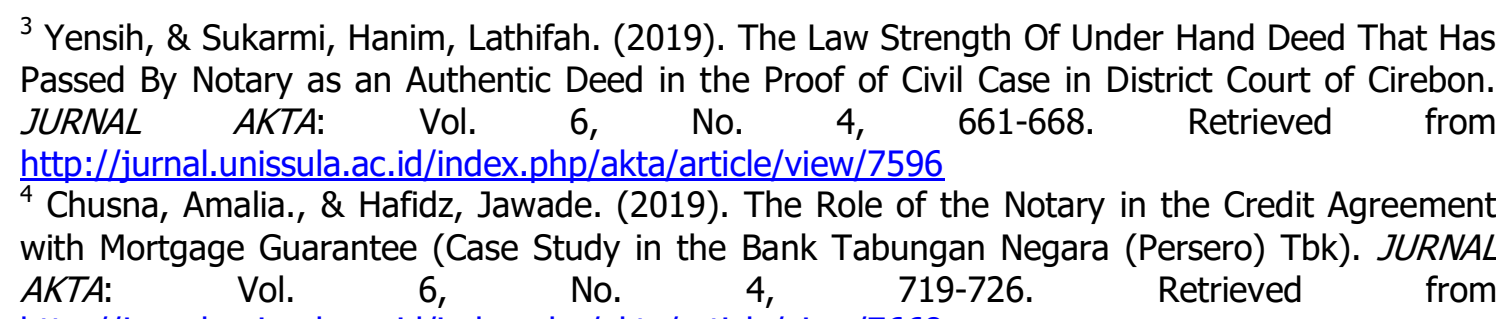
http://jurnal.unissula.ac.id/index.php/akta/article/view/7668

${ }^{5}$ Rahardjo, Satjipto. (1991). IImu Hukum, Bandung: PT Citra Aditya Bakti, p.48

${ }^{6}$ Adigita, Monicha R., Ma'ruf, Umar., \& Witasari, Aryani. (2019). The Role and Protection of Laws to Notary Related To the Dispute That Made Between the Parties. JURNAL AKTA: Vol. 6, No. 4, 783-788. Retrieved from http://jurnal.unissula.ac.id/index.php/akta/article/view/7631

7 Ibid.

${ }^{8}$ Putra, Axel Budi., \& Maryanto. (2019). Legal Analysis of the Form Deed of Sale and Purchase Agreements and the Disposal of Land Rights as the Basic Right to Apply Broking Which Has Expired. JURNAL AKTA: Vol. 6, No. 4, 733-740. Retrieved from http://jurnal.unissula.ac.id/index.php/akta/article/view/7624

9 Ferdiyanti, M. Indah Verena., Purnawan, Amin., \& Soegiyanto. (2019). Setting the Effectiveness of Law Position and Code Notary to the Quality of Performance. JURNAL AKTA: Vol. 6, No. 4, 797-804. Retrieved from http://jurnal.unissula.ac.id/index.php/akta/article/view/7887 


\section{a. There is A Codification System}

The reason why the Civil Law system adheres to codification is partly because of the political interests of the Roman Empire, as well as other interests outside of it. Codification is needed to create uniformity of law within and in the midst of legal diversity. In order for customs that have been established as king's regulations to become generally applicable laws, it is necessary to consider a certain legal entity. That thought, the solution is the need for a codification of law $^{10}$.

b. Judges are Not Bound to Precedent

Nurul quoted the opinion of Paul Scholten who said that the purpose of organizing the Dutch state organs was about the separation between powers to make laws, judicial power and the cassation system and executive power, and it was not possible for one power to interfere with the affairs of another, in this way it was formed ${ }^{11}$.

c. The Judiciary Adheres to the Inquisitorial System

In this system, judges have a big role in directing and deciding cases. Judges are active in finding legal facts and careful in evaluating evidence.

Judges in the Civil Law system try to get a complete picture of the events they have faced from the start. This system relies on the professionalism and honesty of judges ${ }^{12}$.

\subsection{Characteristics of The Common Law System}

a. Jurisprudence as The Main Source of Law

There are 2 (two) reasons why jurisprudence is embraced in the Common Law system, namely ${ }^{13}$ :

1) Psychological reasons

The reason is that every person who is assigned to settle a case tends as much as possible to find justification for his decision by referring to the decision that has been there before, rather than taking responsibility for the decision he makes himself ${ }^{14}$.

2) Practical reasons

It is hoped that there will be uniform decisions because it is often stated that the law must have certainty rather than accentuate justice in every concrete case. In addition, according to the Common Law system, placing

\footnotetext{
${ }^{10}$ Harjanto, Fery., \& Gunarto. (2018). Effects Of Creation Deed of Sale and Purchase of Land Which Does Not Match Procedure of Making Land Deeds. JURNAL AKTA: Vol. 5, No. 4, 857-864. Retrieved from http://jurnal.unissula.ac.id/index.php/akta/article/view/3718

${ }^{11}$ Widyawati, \& Handoko, Widhi. (2018). The Notary Role / PPAT in Improving Legal Awareness Society to Perform Registration Rights to Land Based on Government Regulation No. 24 of 1997 on Land Registration. JURNAL AKTA: Vol. 5, No. 4, 975-980. Retrieved from http://jurnal.unissula.ac.id/index.php/akta/article/view/4127

12 Ibid.

${ }^{13}$ Qamar, Nurul. (2010). Perbandingan Sistem Hukum dan Peradilan Civil Law System dan Common Law System, Makassar: Pustaka Refleksi, p.69-70

${ }^{14}$ Ibid., p.71
} 
the law as the main reference is a dangerous act because the statutory rules are the work of the theorists which are not impossible to differ from reality and are not in sync with needs. After all, as time went on, the law was no longer in accordance with the existing conditions, so it needed court interpretation ${ }^{15}$.

\section{b. Adherence to the Stare Decicis / Precedent Doctrine}

This doctrine substantially implies that judges are bound to follow and / or apply previous court decisions, whether they have made themselves or their predecessors for similar cases ${ }^{16}$. Even though in the Common Law system, it is said that the Stare Decisis doctrine applies, this does not mean that there is no possibility of deviations by the court, by distinguishing it, as long as the court can prove that the facts faced are different from the facts that have been decided by the previous court. This means that the new facts are stated to be not the same as the facts that have precedent ${ }^{17}$.

\section{c. Adversary System in Judicial Process}

In this system, both parties to a dispute each use their own lawyer in front of the judge. The parties each devise strategies in such a way and present as many arguments and evidence as possible in court. So those in a case are opponents between one another, led by their respective lawyers ${ }^{18}$.

\subsection{Notary Concept in Civil Law and Common Law}

Notaries as legal practitioners must broaden their knowledge and intellectual skills to understand the applicable legal systems. It is necessary to understand the legal system of the country where the company is a business partner, in addition to the national legal system where the company is located. In fact, the need for a legal system is even stronger if there is a dispute with other businessmen whose country's legal system is different from the two major legal systems as these are often used in matters of settlement, namely Common Law and Civil Law ${ }^{19}$.

Notary jobs are also affected by the development of the business world. Notary is one of the legal practitioners who need to be careful to understand the difference in the concept of notary office and its impact in the two major legal traditions above.

Herlien Budiono ${ }^{20}$, a senior notary with a doctorate from Leiden University in the Netherlands (2001) has explained the basic comparison of the two legal systems, especially notaries. He conveyed this explanation in front of the participants of the international seminar of the Indonesian Notary Association in Bali in early September. What are the differences ${ }^{21}$ ?

${ }^{15}$ Deen, Thaufiq., Victoria, O. Argo., \& Sumain. (2018). Public Notary Services In Malaysia. JURNAL AKTA: Vol. 5, No. 4, 1017-1026. Retrieved from http://jurnal.unissula.ac.id/index.php/akta/article/view/4135

${ }_{16}$ Ibid.

17 Op.Cit.

18 Ibid.

19 Budiono, Herlien. (2015). Kumpulan Hukum Perdata Di Bidang kenotariatan, Third Book, Bandung: PT Citra Aditya Bakti, p.183

20 Ibid.

${ }^{21}$ Arrohim, Mohammad B., \& Wahyuningsih, Sri Endah. (2020). Analysis of Judicial Application of Criminal Penalty Against Notary / Land Deed Officials Conducting Making Crime of the Fake 
First, the official terms used. Notary is the term for a notary within the Latin "notariat" or Civil Law, whereas in the Common Law system the term notary public is usually used.

Second, a notary as a general official at a Latin "notariat" is carried out by a legal expert (jurist) and there are additional procedures ranging from special education, examinations, to internships that must be taken. Meanwhile, to serve as a notary public does not always require additional special education or internships.

There are various ways of appointment of a notary public in the UK and the United States. In London, England there is a type of advocate known as a solicitor who has the right to carry out the function of notary public. In the United States, there are two types of advocates, namely attorney and counselor at law, who can be appointed as notary public without any special education required. They are appointed by the secretary of state for a maximum term of 2 (two) years and can be re-appointed each time ${ }^{22}$.

Third, the issue of authority. Notary is a public official who has the right to make all deeds authentic, as long as they are not excluded by law. The Latin "notariat" has a monopoly in making authentic notary deeds in the field of private law, although notaries are not the only authentic deed-making officials. The main job of the notary public is stating the correctness of the signature or in the case of a money order protest. In general, the practice of notary public is to give advice, prepare documents, especially documents for the purposes of contractual relations with foreign countries.

In the United States the power of notary public is nothing more than the creation of a limited certificate and that authority cannot be extended. In short, it is only limited to a legalization or determination of the certainty of the date and the signature of the person who affixed $\mathrm{it}^{23}$.

According to Article 135 of the New York Executive Law, the duties of notary public are limited to: to administer oaths and affirmations (take an oath or promise and make a certificate stating that); to take affidavits and depositions (depositions are writings / statements under oath or promise given by a witness); to receive and certify acknowledgments (giving a statement of the truth that on a certain date a certain person has signed a document as described above); to demand acceptance or payment of foreign and inland bills of exchange etc. (draw up a certificate confirming that he has offered on a certain date a money order and protests against a payment for which for some reason the payment has been refused etc.).

Fourth, the difference in the power of proof. In a country with a traditional root in the Civil Law system, such as Indonesia, there are known types of written proof. This can be in the form of an authentic deed or a deed under hand. An authentic deed is one proof of writing, the form and procedure for making it is regulated by law ${ }^{24}$.

Notary is an official who is authorized to produce written evidence in the form of an authentic deed with a compelling nature of evidence (een dwingende bewijskracht).

Authentic Deed in State Court of Semarang. JURNAL AKTA: Vol.7, No. 2, 183-188. Retrieved from http://jurnal.unissula.ac.id/index.php/akta/article/view/7891

${ }^{22}$ Article 130 New York Executive Law

${ }^{23}$ Op.Cit.

${ }^{24}$ Articles 1867 and 1868 of the Civil Code 
Notary deeds have formal, material proof strength, even in certain legal acts they also have executive power.

Evidence of an authentic deed means that the deed gives an obligation to the opponent to prove the opposite of its contents without the need to prove that the signature of the notary is true and the information made by the notary in the deed is always deemed true. The deed also guarantees the date of creation, who made it and the accuracy of the information provided by the parties ${ }^{25}$.

An authentic deed also functions as an absolute requirement (bestaansvoorwaarde) based on law for the existence of a legal action or event. For example, the establishment of a limited liability company is formed by a notary deed in Indonesian and is established by two persons / legal subjects ${ }^{26}$.

This is totally different from the strength of public notary deeds whose legal system does not pay much attention to writing as evidence. So, there is no known distinction such as authentic deed and underhand deed in public notary products. The product of ratification of notary public documents is in many ways the same as the purpose of legalization according to Article 15 paragraph (2a) of the Law on Notary Office rather than as strong written evidence.

The United States, United Kingdom, Ireland, Australia, New Zealand, Canada except Quebec and several Asian and African countries that have been colonies use the Common Law tradition. Several areas of Western Europe, such as Germany, Italy, Spain, Portugal, Greece, the Netherlands, France and countries in Asia and Africa that had been colonized or colonized, were influenced by the Corpus Iuris Civilis in the Civil Law tradition ${ }^{27}$.

\section{CLOSING}

\subsection{Conclusion}

In the matter of notary system many countries use different system even Civil Law or Common Law. As for ASEAN member countries, they have too the differential in their legal systems. For example, Indonesia and Vietnam are influenced by the Civil Law system. Singapore and Malaysia mostly follow the Common Law system, while Thailand and the Philippines adhere to a mixed system of the two. This is the various kind of the law system which adapted with their own condition.

\subsection{Suggestion}

By knowing the difference in this concept, hopefully legal practitioners will be more careful in accepting notary public product documents if they are conducting crossborder transactions.

\section{References}

Journals:

Adigita, Monicha R., Ma'ruf, Umar., \& Witasari, Aryani. (2019). The Role and Protection of Laws to Notary Related To the Dispute That Made Between the Parties.

\footnotetext{
${ }^{25}$ Ibid.

${ }^{26}$ Article 1 number 1 of Act No. 40 of 2007 on Limited Liability Companies

27 Ibid.
} 
JURNAL AKTA: Vol. 6, No. 4, 783-788. Retrieved from http://jurnal.unissula.ac.id/index.php/akta/article/view/7631

Arrohim, Mohammad B., \& Wahyuningsih, Sri Endah. (2020). Analysis of Judicial Application of Criminal Penalty Against Notary / Land Deed Officials Conducting Making Crime of the Fake Authentic Deed in State Court of Semarang. JURNAL AKTA: Vol.7, No. 2, 183-188. Retrieved from http://jurnal.unissula.ac.id/index.php/akta/article/view/7891

Budiono, Herlien. (2015). Kumpulan Hukum Perdata Di Bidang kenotariatan, Third Book, Bandung: PT Citra Aditya Bakti, p.183

Chusna, Amalia., \& Hafidz, Jawade. (2019). The Role of the Notary in the Credit Agreement with Mortgage Guarantee (Case Study in the Bank Tabungan Negara (Persero) Tbk). JURNAL AKTA: Vol. 6, No. 4, 719-726. Retrieved from http://jurnal.unissula.ac.id/index.php/akta/article/view/7668

Deen, Thaufiq., Victoria, O. Argo., \& Sumain. (2018). Public Notary Services In Malaysia. JURNAL AKTA: Vol. 5, No. 4, 1017-1026. Retrieved from http://jurnal.unissula.ac.id/index.php/akta/article/view/4135

Ferdiyanti, M. Indah Verena., Purnawan, Amin., \& Soegiyanto. (2019). Setting the Effectiveness of Law Position and Code Notary to the Quality of Performance. JURNAL AKTA: Vol. 6, No. 4, 797-804. Retrieved from http://jurnal.unissula.ac.id/index.php/akta/article/view/7887

Harjanto, Fery., \& Gunarto. (2018). Effects Of Creation Deed of Sale and Purchase of Land Which Does Not Match Procedure of Making Land Deeds. JURNAL AKTA: Vol. 5, No. 4, 857-864. Retrieved from http://jurnal.unissula.ac.id/index.php/akta/article/view/3718

Putra, Axel Budi., \& Maryanto. (2019). Legal Analysis of the Form Deed of Sale and Purchase Agreements and the Disposal of Land Rights as the Basic Right to Apply Broking Which Has Expired. JURNAL AKTA: Vol. 6, No. 4, 733-740. Retrieved from http://jurnal.unissula.ac.id/index.php/akta/article/view/7624

Saputri, Anindia I., \& Witasari, Aryani. (2020). Notary Role In Making The Deed Of Murabahah Financing On Islamic Bank (Review On Financing Agreement In Islamic Bank Of Central Java). JURNAL AKTA: Vol.7, No. 2, 229-236. Retrieved from http://jurnal.unissula.ac.id/index.php/akta/article/view/7874

Wahyuni, \& Ma'ruf, Umar. (2020). The function of the Notary / PPAT In filing process Acquisition of Land Rights To Interests Investment in Regional Autonomy Era Based on Act No. 25 of 2007 concerning Foreign Investment. JURNAL AKTA: Vol.7, No. 2, 189-194. Retrieved from http://jurnal.unissula.ac.id/index.php/akta/article/view/7965

Widyawati, \& Handoko, Widhi. (2018). The Notary Role / PPAT in Improving Legal Awareness Society to Perform Registration Rights to Land Based on Government Regulation No. 24 of 1997 on Land Registration. JURNAL AKTA: Vol. 5, No. 4, 975-980. Retrieved from http://jurnal.unissula.ac.id/index.php/akta/article/view/4127 
Yensih, \& Sukarmi, Hanim, Lathifah. (2019). The Law Strength Of Under Hand Deed That Has Passed By Notary as an Authentic Deed in the Proof of Civil Case in District Court of Cirebon. JURNAL AKTA: Vol. 6, No. 4, 661-668. Retrieved from http://jurnal.unissula.ac.id/index.php/akta/article/view/7596

Books:

Qamar, Nurul. (2010). Perbandingan Sistem Hukum dan Peradilan Civil Law System dan Common Law System, Makassar: Pustaka Refleksi

Rahardjo, Satjipto. (1991). IImu Hukum, Bandung: PT Citra Aditya Bakti

Regulations:

1945 Constitution

Act No. 40 of 2007 on Limited Liability Companies

Article 135 of the New York Executive Law

Articles 1867 and 1868 of the Civil Code

Staatsblad of 1909 No. 291 concerning the Legalization of Signatures and on the Ratification of the 1961 Vienna Convention on Diplomatic Relations and its Operational Protocols 